\title{
FILSAFAT EKSISTENSIALISME: SEBUAH KEMUNGKINAN PILIHAN HIDUP YANG SEJATI
}

\author{
Wilhelmus Jemarut \\ IAHN Gde Pudja Mataram \\ yohaneshadit@gmail.com \\ Kondradus Sandur \\ Alumnus STFK Ledalero
}

\begin{abstract}
Abstraksi
Kekaguman akan dunia digumuli dalam filsfat. Darinya bersemi sebuah cara pandang baru tentang mencintai kebijaksanaan, philo-sophia. Mencintai kebijaksanaan dimulai dari rasa kagum akan dunia. Perlahan dunia dipertanyakan secara mendalam. Ia membentuk cara berpikir. Cakrawala berpikir membuahkan tindakan atas jalan filsafat. Perilaku adalah praksis hidup filsafat. Filsafat eksistensialisme merupakan salah satu cara kultur filsfat kontemporer. Ia lahir pada awal abad ke-20 sebagai bentuk kritik terhadap filsfat barat dan dogmatisme agama. Kecenderungan filsafat barat yang abstrak dan idealistik menelurkan corak berpikir yakni kembali kepada subjek manusia yang sadar akan dirinya sendiri. Jenis kesadaran tersebut dikembalikan pada subjek manusia yang aktif dan merancang masa depan sendiri. Kemampuan manusia untuk merancang masa depan sendiri mendongkel dogmatisme agama yang rigid. Filsafat eksistensialis membuka prespektif baru tentang cara berada manusia. Itulah praksis filsfat eksistensialisme.
\end{abstract}

\section{Kata kunci: Filsafat, Eksistensialisme, Pilihan Hidup}

\section{Pendahuluan}

Hidup sering ditandai oleh dua garis pemisah, yakni hitam dan putih. Hitam berarti kekelaman, keburukan dan keputusasaan. Putih berarti kebahagiaan, kesejahteraan dan perdamaian. Evaluasi terhadap dua cara pandang ini begitu gamblang. Yang satu dianggap baik, sedangkan yang satu dianggap buruk. Batasannya seakan diterima begitu saja tanpa dipersoalkan secara lebih jernih. Hasilnya kita cenderung menolak keburukan dan mengafirmasi kebahagiaan. Padahal, keduanya tidak bertahan lama. Ia datang silih berganti. Namun, itulah perjalanan hidup, ia tidak serta merta mulus. Bagaiakan dua sisi mata uang yang sama, ia selalu hadir. Kehadirannya adalah mutlak. Keduanya saling mengandaikan dan tidak terbantahkan satu sama lain. Hegel mengatakannya sebagai bentuk dialektika dalam hidup. Keburukan sebagai antitesis terhadap kebaikan dan sebaliknya. Bagaikan siklis, keburukan dan kebaikan datang silih berganti dan tidak berujung.

Tugas filsafat sebagai ilmu memberikan batasan pada nilai, isi dan universalitas. Nilai berhubungan dengan kebaikan dan keburukan; kebenaran dan ketidakbenaran; 
keindahan dan keburukan; kemalangan dan kesejahteraan. Isi berhubungan dengan materi yang terkandung dalam filsafat sendiri yakni kenyataan yang ada. Menurut Dr. A. C Ewing pertanyaan pokok filsafat adalah kebenaran (truth), materi (matter), mind (akal budi), relation of matter and mind (hubungan materi dan akal budi), space and time (ruang dan waktu), cause (sebab), freedoom (kemerdekaan), monisme vs pluralisme dan Tuhan (God). Luis Kattsoff menegaskan bahwa "lapangan filsafat itu luas, yaitu meliputi segala pengetahuan manusia serta segala sesuatu yang ingin diketahui oleh manusia”.

Sebelum para filsuf kontemporer menguraikan tentang membangun tatanan hidup yang lebih baik di panggung besar sepert negara, komunitas dan budaya, filsfuf klasik telah menggariskan tatanan hidup manusia dengan ciri mikrokosmos. Didalamnya diuraikan bahwa manusia merupakan gambaran mini alam semesta. Ini ditandai oleh adanya ciri fisik dan jiwa yang dimiliki manusia. Ciri tersebut menggambarkan manusia yang utuh. Jiwa, badan dan kehendak manusia memungkinkan sebuah pengertian tentang dirinya sendiri dan makhluk disekitarnya. Tidak berhenti pada pengertian semata, setiap orang mempunyai caranya sendiri untuk mengenal sesuatu yang berada di sekitarnya. Rasa kagum akan dunia dipertanyakan oleh manusia. Sehingga ia mengetahui sesuatu dan menjadikannya sebagai bekal dalam menjalankan hidupnya sendiri. Kesatuan antara pengetahuan dan tindakan hidup manusia dikatakan oleh Aristoteles sebagai arete atau keutamaan hidup.

\section{Metodologi Penelitian}

Penelitian ini adalah penelitian kualitatif dalam bidang filsafat yang dilakukan dengan library research, yaitu mengkaji beberapa sumber pustaka terkait pemikiran eksistensialisme dan hubungannya dengan kehidupan manusia secara umum. Proses analisa yang dilakukan adalah dengan menggunakan metode hermeneutika filosofis, menurut Anton Bakker (2004) terdapat beberapa unsur metodis dari penggunaan metode hermeneutika tersebut, yaitu:

1. Interpretasi, memahami konsep-konsep di dalam pemikiran Eksistensialisme berdasar latar belakang pemikiran yang dikaji tersebut.

2. Holistik, memahami secara komprehensif berbagai aspek yang menjadi acuan.

3. Idealisasi, memahami menurut dinamika dan inti semurni mungkin 
4. Refleksi, mengungkap relevansi pemikiran eksistensialisme sebagai kemungkinan pilihan hidup yang sejati.

\section{Hasil dan Pembahasan}

\section{Filsafat dan Kompleksitas Manusia}

Pergumulan tentang hidup manusia yang sangat kompleks disadari tidak cukup dengan ilmu pengetahuan. Ilmu pengetahuan dikatakan tidak dapat mengupas tuntas tentang problematika hidup manusia. Beberapa pakar mengatakan bahwa ilmu pengetahuan merupakan panduan teknis terhadap persoalan manusia. Hal teknis tersebut belum cukup untuk menuntaskan persoalan manusia yang kompleks. Manusia tidak dapat ditakar dari kondisi parsial teknis. Ada yang menelisik pengetahuan dari sudut pandang biologi, fisika, sosiologi, antropologi dan seterusnya. Masing-masing ilmu mempunyai cara dan metodenya sendiri. Sehingga dari kajian tersebut manusia ditilik dari prespektif yang khusus. Sementara manusia mempunyai ciri multidimensi dalam hidupnya. Di sana terbentang nilai-nilai, sikap hidup, perasaan dan pikiran.

Berkaitan dengan itu filsafat mempunyai metodenya sendiri dalam berhadapan dengan kompleksitas manusia. Sebagai ilmu pengetahuan, filsafat membantu manusia untuk mengejar kebijaksanaan dan keutamaan hidup. Ia melampaui tindakan teknis ilmu pengetahuan lainnya. Dalam arti bahwa filsafat berupaya untuk mendekatkan seluruh pertanyaan tentang manusia sampai pada titik mendekati kesempurnaan. Filsafat berupaya untuk mengejar arti, nilai dan tujuan hidup yang melampaui ilmu pengetahuan dan teknologi.

Pergumulan manusia mencapai sebuah kesempurnaan hidup atau kebijaksanaan dalam filsafat berpatokan pada metode berikut: pertama, pencarian yang tidak kunjung akhir akan hidup manusia. Tentang manusia tidak hanya dipertanyakan apa yang manusia makan agar bertahan hidup? Jauh lebih dari itu, filsafat mempertanyakan untuk apa manusia makan dan bagaimana manusia mendapatkan makanan itu serta makna makanan bagi kehidupan pada umumnya. Kedua, filsafat berupaya untuk mencari sintesis dari ilmu-ilmu pengetahuan lainnya. Ia tidak hanya berhenti pada pencarian akan suatu akar persoalan, tetapi ia pun mengandaikan ilmu-ilmu pengetahuan lainnya sambil mencari pusat dari seluruh pencarian manusia. Ketiga, filsafat menjawabi kebuntuhan ilmu pengetahuan tentang hakikat manusia yang sebenarnya. Manusia sendiri sangat 
tidak puas dengan ilmu pengetahuan. Bahkan ia akan mencari mengapa ilmu pengetahuan itu harus ada dalam menunjang kehidupannya.

Filsafat sangat dekat dengan kehidupan manusia. Ia membahas bagaimana manusia hidup di dunia ini dengan perbagai problem yang ada. Kenyataan hidup manusia seperti penderitaan, kebahagiaan, keputusasaan dan nilai-nilai hidup dipertajam dalam filsafat. Filsafat juga membahas manusia dengan setiap hasil peradaban nya, seperti hal nya dengan teknologi yang menurut pendapat Erich Fromm (dalam Noorzeha, 2020) bahwa saat ini secara tidak sadar manusia tergerus dengan ciptaan nya itu sendiri. Filsafat selalu mempersoalkan semuanya itu sampai pada titik tertentu, setiap orang yang belajar filsafat memperoleh gambaran yang jernih tentang hidupnya. Pembahasan filsfat sebagai pergumulan situasi hidup diterangkan dalam filsafat eksistensialisme. Eksistensialisme mempertanyakan keberadaan manusia secara ultimum, yakni apakah manusia mempunyai makna. Jika itu ada, makna bagaimana yang mesti dijawab oleh manusia (Weij, 2017:4).

Filsafat eksistenislisme mempergunjing keberadaan manusia di tengah perubahan. Sebagai makhluk penanya, hakikatnya manusia mempersoalkan segala sesuatu yang berada di sekelilingnya. Bahkan secara radikal, ia mempertanyakan tentang keberadaannya sendiri. Tidak berhenti pada penjajagakan tentang kemungkinan hidup di dunia, manusia mempersoalkannya sampai pada proses kehidupan sesudah kematian. Dua tendensi filsafat eksistensialisme adalah tentang kemungkinan-kemungkinan hidup yang dijalankan oleh manusia dan makna hidup sebagai pilihan hidup untuk menjawab perubahan yang sedang terjadi.

Sejak ribuan tahun yang lalu, para pemikir Yunani Kuno telah memperlihatkan proses mengenal tersebut. Mereka menyebut ruang lingkup tempat mereka tinggal dan berinteraksi dengan nama cosmos. Melalui kosmos itu, mereka bertanya-tanya tentang asal muasal segala sesuatu. Apakah ia berwujud kekal, tidak berubah-ubah ataukah ia berwujud tetap? Namun suatu sikap kepastian adalah bahwa mereka harus hidup selaras dengan alam yang berada di seputarnya. Hidup harmoni dengan alam dilakukan melalui berpikir tentang tatanan dunia tersebut. Demikian mereka menyebutnya dengan istilahbios theoretikos.

Bios theoretikos berarti berpikir tentang sesuatu yang lebih luhur dan mulia. Yang luhur dan mulia itu tidak terjerembab pada pola perubahan-perubahan dan tetap. Ia menjadi awal segala sesuatu dan tidak dapat digerakan oleh sesuatu yang lainnya. Ia 
adalah prinsip dari segala sesuatu. Dengan demikian hidup selaras alam mempunyai ciri bertengadah pada sebuah prinsip yang luhur dan mulia. Kesesuaian antara cara berpikir dan pengaruh konteks mereka hidup menyebabkan mereka merenung tentang dunia (Hardiman, 2009: 21-23)

Demikian yang tampak pada filsuf Ionia, Abad ke-6, Thales menyebut prinsip dasar yang ada di muka bumi adalah air. Anaximenes menyebutnya udara dan Anaximandros menyebutnya sebagai to apeiron (yang tak terbatas). Itulah prinsip utama dari tatanan dunia yang mereka hidup setiap harinya. Prinsip dasar tersebut mereka sebut sebagai arche (Weij, 2017: 14-46). Bergerak dari benda-benda materi tersebut, pada Mazab Elea mempertanyakan tentang sesuatu yang mungkin menjadi penggerak dari keberadaan benda-benda itu. Mereka menyebutnya sebagai Ada. Ia tidak digerakkan, tidak berubah dan tetap. Hal ini menunjukkan suatu perubahan cara pandang mengenai realitas. Bertolak belakang dengan Heraklitos (544-575) yang mengatakan bahwa tidak ada yang tetap di bumi ini; semuanya bergerak dan tidak kembali pada keadaan semulanya, Permanides (540-570 SM) mengatakan bahwa Yang Ada itu tetap dan tidak bergerak oleh apapun. Itulah ciri rasionalitas para filsuf Barat Kuno. Mereka melakukan pembuktian-pembuktian teoritis akal budi tentang pengetahuan manusia.

Plato (427-347 SM) menjelaskan bahwa manusia mempunyai tatanan khusus yakni jiwa. Jiwa memiliki tiga bagian dan masing-masing bagian mempunyai fungsinya. Ketiganya adalah keinginan (epithymia), energi (thymos), dan bagian rasional (logos). Ia menyandingkan tiga fungsi tersebut dengan komponen dalam masyarakat, yakni keinginan terdapat pada kalangan buruh, pedagang dan petani. Sedangkan energi dilekatkan pada fungsi prajurit dan logos merupakan tipikal yang dimiliki oleh para pelajar

Jiwa menurutnya merupakan karakter dasar manusia yang memungkinkannya mengenal dunia. Sementara itu, ia memisahkan dunia atas dua ciri, yakni duna yang kelihatan (horaton genos) dan dunia tidak kelihatan (kosmos noetos). Sebelum manusia ada dalam dunia, ia terdahulu sudah mengenal sesuatu yang baik, benar, dan indah melalui jiwanya. Unsur-unsur itu disebutnya dengan nama idea dan memungkinkan manusia untuk mengenal benda-benda konkret.

Unsur-unsur ke-sama-an, ke-benar-an, ke-baik-an dan ke-indah-an sudah dikenal manusia dalam jiwanya sebelum ia berada di bumi. Jiwa tersebut bersekutu dengan sebuah idea, sebagai gambaran ultim, tentang pengenalan manusia. Keberadaan manusia 
di dunia, melalui badannya, menyebabkan unsur persekutuan dengan idea yang maha luruh itu hilang. Namun, manusia masih dimungkinkan untuk mengenal unsur tersebut melalui demiorgos.

Demiorgos, demikian P. A. Van der Weij, melukiskannya sebagai Arsistek Allah dalam diri manusia. Demiorgos memungkinkan manusia dapat mengenal idea yang sama, baik dan indah seperti sediakalanya, ketika ia berada bersama idea di dunia kayangannya. Jadi demiorgos ini menghubungkan manusia dengan dunia ciptaan yang lainnya. Ketika manusia bersentuhan dengan gejala dunia, demiorgos mengembalikan manusia pada idea yang pernah dilihatnya sebelumnya. Jadi demiorgos menjadi alat bantu dalam diri manusia untuk mengenal sebuah idea seperti kebaikan, kebenaran dan keindahan (Weij, 2017: 19-25).

Tentang kemungkinan pengenalan manusia akan sesuatu yang lebih baik, benar dan indah terdorong oleh daya cinta (eros). Eros merupakan daya kreatif manusia, pencetus kehidupan, inspiratur para penemu, seniman dan genius. Cinta itu membawa setiap orang menuju hidup yang lebih terarah pada idea kebaikan, kebenaran dan keindahan. Dengan eros orang mulai mengenal dunia kehidupan yang nyata dan menuju kemungkinan ultimum hidup, yakni kebaikan, kebenaran dan keindahan itu sendiri. Eros bagi Plato merupakan sebuah bentuk menaiki anak tangga. Analogi tangga ini dikatakan sebagai berikut: dengan mengerti (idea) tentang keindahan dari tubuh satu tubuh akan berhubungan dengan tubuh yang lain, pencinta pun akan naik pada peda keindahan badan; dan hanya menanggapi suatu bojek indah yang baru (keindahan jiwa), pencinta akan naik menuju cinta akan keindahan jiwa dan hukum (Konrad Kebung, 2002: 61).

Sementara itu muridnya, Aristoteles (384-322 SM) mendekatkan dunianya melalui penyerapan melalui indera. Dunia menjadi mungkin karena proses abstraksi yang diperoleh melalui pengalaman-pengalaman. Dalam kacamata filosofisnya, proses pengenalan manusia bersumber dari sesuatu yang diinderai. Namun karena unsur inderawi itu berubah-ubah, maka ada sesuatu yang mestinya tetap. Itulah substansi dari segala materi. Ia menjelaskan problem tersebut melalui sebuah analogi patung. Patung pada dasarnya dibuat dari sebuah batu pualam, secara materialnya batu itu tidak berubah, sementara ia mengalami perubaan bentuk di tangan tukang batu. Aristoteles menyebutnya hylemorfisme.

Hylemorfisme didefinisikan sebagai materi (hyle) dan bentuk (morphe). Aristoteles membagi hyle menjadi dua, yakni hyle pertama dan hyle yang kedua. Hyle pertama 
disebut Aristoteles sebagai hyle porte. Ia tidak berbentuk, bukan benda dan mempunyai ciri subtantif. Hyle kedua disebutnya hyle deutra, yakni benda yang kita lihat dan yang dapat diraba atau dipegang. Hyle pertama dan morphe pertama adalah dasar pengenalan manusia tentang segala sesuatu. Akan tetapi, itu dapat dikenal karena dalam diri manusia juga mempunyai daya yakni nus (roh). Nus merupakan gambaran diri yang ilahi yang ada dalam diri manusia. Dengan adanya nus, manusia dapat memproleh gambaran tentang kebahagiaan hidupnya.

Hidup bahagia merupakan puncak pencarian manusia. Menurut Aristoteles hidup manusia menjadi bahagia ketika ia mewujudkan keutamaan (arete) dalam dirinya. Keutamaan yang paling baik dalam diri manusia adalah mengembangkan ciri rasionalnya. Ciri rasional tersebut dikembangkan dengan mengembangkan visi kontemplatif rasio dalam kehidupan sehari-hari. Sebab rasio tidak terarah pada sesuatu yang lain di luar dirinya. Rasio merangkum kebahagiaan hidup manusia yang sempurna. Rasio menjadikan manusia mengarahkan hidupnya pada segala potensi dalam diri yang sifatnya positif. Ciri positif tersebut juga bergantung pada harta kekayaan yang cukup, mempunyai anak-anak yang baik, sahabat-sahabat, keindahan tubuh dan waktu senggang.

Sesudah pencarian panjang dua filsuf klasik Yunani tersebut, filsafat bercumbu dengan kebenaran yang bertendensi pada kebenaran yang bersifat empiris dan rasionalisme. Rasionalisme berpegang pada gagasan akan idea atau rasio sebagai metode yang tepat dalam mengatasi kesimpangsiuran yang terjadi di dunia. Ide merupakan hakikat manusia, Tuhan merupakan penyebab ide sempurna tersebut; karena itu ia mesti ada dan materi merupakan eksistensi atau perluasan dari ide. Hal ini terdapat di ilmu ukur. Demikian gagasan Descrates tentang rasio sebagai kunci akan kebenaran.

Empirisme menekankan hakikat sebaliknya dalam pergumulan manusia tentang kebenaran yakni fakta-fakta yang sifatnya dapat dibuktikan. Karena itu, empirisme menekankan prinsip testibilitas dalam mengemukakan sesuatu. Inti dari empirisme adalah pembuktian akan adanya kebenaran akan sesuatu hal. Pengalaman dan bukan ide sebagai sumber kebenaran. Argumentasi penting yang menjadi rujukan dalam memahami empirisme adalah "sesuatu diklaim sebagai sebuah kebenaran jika itu dapat ditunjukkan bukti-buktinya". Testabilitas kebenaran merupakan tolok ukur dalam empirisme (Benton, 2009:21-22) 
Kedua aliran tersebut sama-sama meletakan manusia sebagai koridor pencarian akan kebenaran. Yang satu menunjukkan rasionya sedangkan yang lainnya menunjukkan pengalaman inderawi. Akan tetapi, satu hal yang dilupakan dari dua aliran tersebut adalah posisi manusia sebagai pencari kebenaran itu sendiri dikesampingkan karena keduanya meletakan posisi manusia sebagai objek dari kajiannya sendiri. Ini terbukti dalam filsfat materialimse dan naturalisme yang menempatkan manusia seperti robot dan benda teknis lainnya. Sementara itu dalam kajian rasionalisme, ide atau rasio merupakan esensi manusia. Manusia dikatakan manusia karena ia mempunyai keunggulan dalam pola pikirnya (Ekawati, 2015).

Rasionalisme melahirkan corak berpikir idealistis. Idealisme mempunyai prinsip bahwa hanya ada ide merupakan sumber kebenaran. Secara ontologis atau asal mula segala sesuatu idea lebih awal ada daripada benda materi. Materi merupakan perluasan dari dunia idea. Hal ini dapat ditelusuri dalam gagasan Plato tentang sumber segala sesuatu adalah idea. Idea sebagai sumber pengetahuan atau dalam kajian ilmu pengetahuan, idea merupakan bentuk yang tertinggi sumber pengetahuan. Konstruksi mengenal dan mengetahui dalam diri manusia dilakukan dengan cara mengingat kembali segala sesuatu yang sudah ada dalam pikiran manusia. Serentak sesuatu dikatakan benar, jika itu membentuk sebuah hubungan logis antara apa yang ada dalam ide dengan kenyataan yang ada di luar gagasan manusia. UntukIa merupakan sumber kebenaran sejati karena ia mempunyai ciri universal, abadi dan tidak berubah. Menjejaki ciri idealistik tersebut merupakan sumber nilai (estetika) dalam hidup (Rusdi, 2013).

Seturut pemikiran G. Hegel (1770-1831 M), bentuk nilai yang tertinggi adalah kebenaran yang mendekatkan diri pada ciri Roh Absolut. Ia berada pada wilayah kesadaran melalui ciri dialektika antara ide abstrak (pemikir) dan alam (yang dipikirkan). Roh tersebut menjernihkan pertentangan antara ide dan alam konkret. Ia sudah melewati alam konkret dan menjadi sadar akan keberadaan dirinya. Namun itu berciri perorangan atau subjektif seturut pemikiran Hegel. Ia akan menjadi konkret (objektif) ketika ia terejawantahkan dalam kesadaran yang lebih luas seperti keluarga, masyarakat dan negara. Roh absolut tersebut terejawantahkan melalui kesenian, agama dan filsafat. Kesenian terjawantahkan dalam pengalaman inderawi, agama dalam bentuk imajinasi dan filsafat dalam bentuk pengertian (Weij, 2017:118-119).

\section{Filsafat Eksistensialisme}


Filsafat eksistensialisme lahir dari kegusaran akan ciri idealistik Hegel. Melihat roh absolut merupakan segala-galanya, manusia dilihat Hegel secara konkret ketika ia melebur dalam roh absolut seperti keluarga, masyarakat dan negara. Hegel tidak melihat keutuhan manusia secara pribadi. Karena itu ia mengatakan kesadaran pribadi sebagai perjalanan roh sebagai kesadaran subjektif. Tentu hal tersebut dapat menciptakan sebuah pendangkalan akan hakikat manusia sebagai seorang individu. Ciri individu manusia seakan tenggelam dalam ciri universal seperti keluarga, masyarakat dan negara. Dengan kata lain, sejarah peradaban tidak ditentukan oleh pribadi individu-manusia konkret tetapi oleh kolektivitas dan universalitas sejarah bangsa (volkgeist)

Kegusaran akan filsafat idealistik ditelurkan oleh Soren Kierkegaard (1813-1835). Kierkegaard dikenal sebagai tokoh pencetus eksistensialisme. Ia menentang gagasan Hegel tentang roh absolut Hegel. Baginya roh absolut Hegel meruntuhkan manusia sebagai individu. Manusia memang hidup dalam kebersamaan tetapi kebersamaan tidak seharusnya merendahkan ciri manusia sebagai pribadi yang utuh. Gagasan filsfat Hegel dapat meruntuhkan hidup individu dan tidak manusiawi. Baginya kebenaran sejati mesti dihayati oleh individu. Tidak ada faedahnya segala ilmu pengetahuan manusia dan gambaran abstrak dan umum apabila itu tidak dijiwai oleh individu-individu. Ia mengatakan bahwa tidak ada faedahnya beragama apabila arti beragama itu tidak mempunyai arti untuk diri sendiri (Ibid, hlm. 160).

Poin penting Kierkegaard adalah kebenaran umum dan roh absolut yang dimaksudkan oleh Hegel mesti menjadi bagian dari realitas hidup individu. Ia berpendapat bahwa pengetahuan itu mesti dihayati oleh siapapun (connaissance vecue). Manusia hidup dalam situasi konkret dan itu hanya dihayati oleh setiap individu. Masing-masing individu mempunyai pengalamannya sendiri. Baginya manusia tidak bersandar pada kebenaran umum dan jika itu terjadi maka cirinya adalah estetis. Ia mengumpamakan pengalaman hidup manusia yang konkret sebagai tahapan pembelajaran dalam diri seorang anak.

Seorang anak yang baru belajar sesuatu mempunyai pandangan subjektifnya sendiri. Di sana seorang anak belum menjadi dirinya sendiri. Perlahan-lahan ia akan mulai belajar agar lebih paham tentang aturan, norma dan nilai-nilai dalam masyarakat. Sehingga ia menjadi seorang persona. Ciri persona manusia tidak sempurna. Ia akan mengalami tegangan antara harapan menjadi sempurna dan kerapuhan dalam dirinya 
sendiri. Oleh karena itu, ia belajar menjadi manusia yang religius. Pada tahapan ini ia belajar untuk menyadari dirinya sebagai orang yang tidak sempurna. Justru dalam ketidaksempurnaan tersebut ia mulai bersandar pada Tuhan yang maha sempurna.

Cara pandang Kierkegaard menunjukkan bahwa manusia hidup dalam tegangantegangan konkret. Manusia merasakan emosi, gagal, marah, benci dan seterusnya. Sejalan dengan itu, ia pun mempunyai kemampuan dalam dirinya untuk belajar menjadi lebih baik dan hidup seturut nilai-nilai yang dihayati bersama. Situasi-situasi tersebut merupakan keadaan konkret manusia (ensiklopedia.kemdikbud.go.id, diakses 30 Oktober 2019). Terminologi kunci dalam filsafat eksistensialis adalah manusia yang selalu dinamis. Pelbagai kemungkinan menjadi pilihan hidup setiap orang. Ia tidak statis melainkan aktif, berbuat dan selalu menjadi baru dalam pergumulan hidupnya. Ciri aktif ditandai oleh usahanya untuk mencari dan menemukan suatu hidup yang lebih bermakna. Kebermaknaanya ditandai oleh ciri berbuat dan menghayati hidup seturut pengalaman dan realitas konkret: kegelisahan dan sukacita; kemurungan dan kegembiraan; penderitaan dan kesenangan. Tegangan-tegangan tersebut merupakan titik-titik pencarian setiap manusia akan hidupnya yang selalu menjadi dan tidak statis. Sehingga pada akhirnya ia selalu menjadi baru di setiap tahapan pergumulan hidupnya. Beberapa kemungkinan memaknai hidup dijumpai dalam pandangan beberapa filsuf eksistensialis diantaranya adalah Friedrich Wilhelm Nietzsche (1844-1900). Karl Jaspers (18831969), Gabriel Marcel (1889-1973) dan Jean-Paul Sartre (1905--1980).

\section{Kemungkinan Pilihan Hidup}

\section{Individual}

Ciri mendasar manusia adalah pribadi atau individu. Sebagai seorang individu, kita unik dan tidak dapat disamakan dengan yang lainnya. Ia tidak didominasi oleh kolektivitas manusia pada umumnya. Hal ini menjadi tanggapan Kierkegaard atas Hegel. Ia merasa yakin bahwa setiap individu mempunyai keunikan tersendiri dalam menghadapi setiap peristiwa atau kejadian dalam hidup. Ia menentang bahwa roh absolut yang melintasi sejarah manusia pada umumnya menjadi titik tolak kesadaran manusia dalam mengarungi hidup. Ia menunjukkan sisi ilahi dari setiap pergumulan manusia. Ini tentu tidak didorong oleh ciri alur massa. Dalam kerumunan massa tidak ada keotentikan hidup. Dalamnya setiap gambaran diri menjadi kabur dan terkesan verbalisme karena itu mengikuti aturan yang umum terjadi. 
Hal penting dalam filsafat Kierkegaard adalah penghayatan akan diri yang unik. Dalam keunikan diri dipancarkan sebuah keyakinan akan kebenaran. Menurutnya kebenaran setiap orang terpantul dari cara penghayatan pengetahuan, agama, kepercayaan, ilmu pengetahuan dalam menghadapi setiap realitas. Masyarakat, agama, keseniaan dan seterusnya seperti yang dikumandangkan dalam filsafat Hegel tidak berarti sama sekali apabila secara individu manusia tidak menghayati apa menjadi kesadaran bersama. Pemahaman tentang diri yang sejati diaktualisasikan dengan menghayati apa yang diketahui dan dimengerti sepanjang hidup (Weij, 2017: 160).

Kierkegaard menyadari bahwa setiap individu mengalami perkembangan dalam hidupnya. Itulah ciri lain dari manusia, yakni tidak statis. Dinamika manusia dinyatakannya melalui tiga tipe hidup. Pertama, tipe estetis. Di sini setiap individu belum mempunyai prinsip atas hidup yang dijalankannya. Bahkan bimbingan dan tuntunan dari orang lain menjadi penting agar hidup menjadi lebih baik. Namun pada tahap ini, ia belum terlibat penuh dan menghayati apa yang dijalankannya. Artinya keterlibatannya belum penuh dengan setiap pilihan hidup. Kedua, setiap individu akan merasa jenuh, cemas, marah dan frustrasi dalam menjalankan hidup.

Akibatnya, ia akan mulai mencari sebuah tatanan yang lebih baik seperti rasa tanggung jawab, kebebasan dan kewajiban sebgai topangan hidup. Inilah ciri etis dari perjalanan hidup manusia. Selanjutnya, sebagai pribadi otonom pilihan moral tersebut tidak selamanya bertahan, ia merasa jenuh sehingga dicari tatanan yang lebih tinggi. Ketiga, pilihan hidup tertinggi baginya adalah religius. Pada tahap ini setiap orang merasakan bahwa hidupnya tidak sempurna. Ia akan mencari penopang dalam hidup. Bagi Kierkegaard, itu adalah Tuhan yang mengarahkan seluruh hidupnya dan serentak dihayati oleh manusia sebagai tujuan tertinggi dalam hidupnya.

\section{Kekuasaan dan Kebebasan}

Tuhan sebagai tujuan akhir dalam pencarian manusia disangkal keras oleh Nietzche (1844-1900). Sebagai seorang eksistensilis, Nietzche menggambarkan ketiadaan Tuhan dalam proses hidup. Ia mendeklarasikan bahwa Tuhan sudah mati (Got is tot). Seruan ini mengguncang tatanan filsfat Barat dan dogma kekristenan. Filsafat Barat dan dogma kekristenan sangat melekat erat dengan ide Plato tentang Tuhan sebagai 
sumber dan tujuan akhir dari proses berpikir. Tuhan dikumandangkan sebagai sumber nilai dan tujuan dari nilai. Nilai-nilai menurut Nietzche mengunci kebebasan manusia untuk menciptakan masa depannya sendiri. Konsekuensinya kematian Tuhan merupakan sebagai titik awal keunggulan manusia dalam menciptakan masa depan sendiri (Munir, 2011).

Kematian Tuhan dipikirkannya sebagai cara baru agar manusia dapat menciptakan bagi dirinya sendiri semacam dewa baru (Ubermensch-manusia super). Titik tolak filsafatnya adalah kehendak untuk berkuasa. Itulah tujuan akhir dari manusia. Setiap orang baginya mempunyai kehendak untuk menjadi unggul dari manusia lain. Hal tersebut mendorong manusia untuk terus menerus mencari dan menemukan jalan sendiri, tanpa Tuhan. Kematian Tuhan membuka selubung nilai dan dogma kekristenan yang menjunjung tinggi hadirnya Tuhan dalam hidup. Manusia super adalah pengejawantahan dari kehendak manusia untuk mencapai kekuasaan tertinggi.

Manusia dalam kacamata Nietzche terlihat unggul dan serentak saling bersaing untuk mencapai kekuasaan. Keunggulan manusia terletak pada kehendak untuk mencapai kekuasaan. Segala sesuatu yang bertujuan untuk meningkatkan daya kekuasaan adalah baik adanya. Seruan tersebut menunjukkan bahwa manusia tidak hanya sebagai puncak evolusi dari peradapan tetapi secara radikal Nietzhe mengumandangkan akan arti penting menjadi manusia konkret di tengah dunia. Di satu sisi ia memiliki daya cipta dalam diri, yakni kehendak dan di sisi lain, kehendak berkuasa tersebut merupakan tujuan agar manusia dapat menyiasati hidup untuk menjadi lebih baik. Namun persaingan adalah dampak lain dari cita-cita Nietzche untuk mencapai kekuasaan. Persaingan meruntuhkan manusia sebagai pribadi yang cinta sosial atau makhluk sosial. Demi kekuasaan semata, sosialitas kehidupan manusia menjadi runtuh dan tidak ada lagi rasa persaudaraan yang sejati.

Radikalisasi keunggulan manusia tampak pada gagasan kebebasan manusia oleh Jean-Paul Sartre (1905-1980). Kebebasan tersebut tampak pada ciri dinamika hidup manusia. Kita tidak statis dan selalu berubah. Justru karena kita berubah maka tidak ada patokan bahwa manusia itu merupakan suatu cetakan yang sudah ditentukan sebelumnya. Manusia berbeda dari binatang karena ia mempunyai kesadaran dalam dirinya untuk berubah. Pada titik tersebut Satre menolak adanya esensi yang ideal dalam diri manusia. Baginya manusia mempunyai ciri sendiri ber-ada atau bereksistensi. Bereksistensi berarti berada secara aktual dalam ruang dan waktu serentak menunjukkan ciri aktif, mencipta 
dan dinamis (Firdaus M. Yunus, Jurnal Al- Ulum Volume. 11, Nomor 2, Desember 2011 Hal. 267-282).

Gagasan filsafat Satre didasarkan pada dua ciri keberadaan manusia, yakni berada pada dirinya sendiri (letre en soi) dan kesadaran diri (letre pour soi). Berada pada diri sendiri berarti benda seperti apa adanya sedangkan kesadaran mempunyai ciri aktif dalam keberadaannya. Kesadaran merupakan subjektivitas murni. Ciri subjektif tersebut menyebabkan manusia memiliki kebebasan untuk secara aktif menciptakan masa depannya. Kodrat manusia bagi Satre adalah ketiadaan. Esensi manusia adalah ketiadaan itu sendiri dan itu tidak mungkin bagi manusia yang selalu aktif. Baginya eksistensi merupakan hakikat manusia (Van der Wij, op,.cit., hal.171-173). Ciri eksistensi manusia adalah kebebasan oleh karena adanya kesadaran (pour soi) untuk menembus ketertutupan ciri kebendaan atau en soi (Firdaus M. Yunus, ob., cit).

Pandangan Nietzche tentang kebebasan memberi jalan menjadi manusia. Oleh karena kebebasannya, manusia dapat berinteraksi dengan manusia lain. Serentak antara satu dengan yang lain sering mengalami perilaku saling mengobjektifkan. Artinya tidak ada yang abadi dalam hubungan tersebut. Karena itu, Nietzche menyebutkan bahwa tidak ada cinta yang pamrih selain peniadan yang tidak berkepanjangan dalam hidup. Dalamnya tersembunyi benih konflik. Orang dapat berkumpul dan bersatu tetapi keberadaan mereka dapat saja berujung pada peniadaan orang lain. Namun itulah manusia yang selalu mensyaratkan manusia lain di tengah kebebasannya untuk menjadi lebih manusiawi. Jadi kebebasan itu selalu berada dalam proses menjadi sampai pada titik manusia direnggut oleh malaikat maut.

\section{Keterbatasan Hidup}

Kebebasan manusia mempunyai batasannya. Itulah yang ditampilkan oleh Karl Jaspers (1883-1969) dalam kajian filosofisnya. Keberadaan manusia sudah dijelaskan banyak sekali oleh ilmu pengetahuan tetapi itu tidak memberikan alasan yang cukup untuk menjawab pertanyaan tentang siapakah saya dan apa yang mesti saya ketahui di dunia. Orientasi Jaspers dalam dunia dijawab melalui kajian filosofis. Jaspers berpendapat bahwa manusia tidak hanya bereksistensi atau berada dalam dunia. Ia tidak hanya hidup dalam dirinya sendiri tetapi terarah menuju suatu titik puncak trasendental. Sikap egoistis berlumur dalam sejarah peradapan tetapi ia tidak selalu tertutup dalam dirinya. 
Komunikasi memungkinkan manusia melampaui keterbatasannya. Pertanyaan tentang keberadaan manusia dijawab oleh Jaspers dalam ceramahnya pada tahun 1932. Ia mengelompokan tipikal keberadaan dengan ciri merangkul semua. Merangkul semua merupakan frasa yang digunakan oleh Jaspers sebagai makhluk berkesadaran, semangat dan kemungkinan keberadaan (Hermann Horn, 1993). Kemungkinan keberadaan manusia dijelaskan oleh Jaspers melalui dua hal yang saling mengandaikan yakni antara eksistensi dan akal budi. Akal budi menjelaskan mengenai eksistensi manusia dan serentak eksistensi manusia menyediakan isi untuk dijelaskan oleh akal budi. Keduanya saling berkomunikasi dan memberikan jalan keluar di tengah kebuntuhan hidup. Tidak berhenti pada pola komunikasi sebagai sarna perjumpaan dengan yang lainnya. Jaspers berpendapat kemungkinan bereksistensi hadir dalam ciri-ciri lain seperti penderitaan, kesengsaraan, kemiskinan dan sederetan kemalangan hidup lainya. Jaspers menyebut keadaan ini sebagai situasi tapal batas (Weij, 2017: 166).

Jaspers berpendapat bahwa manusia dapat menemukan kebenaran. Kebenaran dapat dijumpai melalui ilmu pengetahuan dan juga melalui pengalaman konkret. Pengalaman konkret tersebut dapat menghantar manusia untuk mengenal sesuatu yang melampaui dirinya. Kenyataan di sekitar manusia dapat dijadikan sebagai modal dalam pengenalan manusia akan wujud tertinggi. Oritentasi gagasan Jaspers sangat melekat erat dengan pengakuannya akan wujud yang tertinggi. Argumentasinya jelas, yakni jika Allah ada, maka saya mempunyai tuntutan etis mengikuti kaidah Allah tersebut serentak dengannya saya meyakini bahwa segala sesuatu yang ada di dunia dan eksistensi manusia merupakan sesuatu yang sementara.

Dimensi keberadaan manusia oleh Jaspers ditandai oleh keberadaanya sebagai makhluk hidup. Dalam kenyataan manusia mengalami lahir, bertumbuh dan berkembang menjadi lebih dewasa dan pada khirnya mati. Hal ini dimiliki oleh semua makhluk hidup tanpa terkecuali. Kemudian manusia mempunyai kesadaraan murni untuk merangkul segala sesuatu yang berada di luar dirinya. Kesadaran murni memungkinkan manusia menjadi makhluk yang kritis terhadap perubahan disekelilingnya. Dengan pikirannya manusia dapat menciptakan ide-ide dan menghubungkan antara yang khusus dan yang umum. Kemampuan intelek mempunyai keterbatasannya juga karena ia tidak dapat menjangkaui hal-hal yang transendental tanpa melibatkan eksistensi. Eksistensi manusia memungkinkan kesadaran murni, intelek dan keberadaan manusia dapat dihayati. 
Cara berpikir Jaspers menginspirasi kita untuk selalu mengedepankan komunikasi. Komunikasi merupakan cara manusia untuk bereksistensi di dunia. Serentak dengan itu, komunikasi mengandaikan orang lain. Di sini terjadi prinsip saling ketergantungan dalam hidup. Selain itu, Jaspers menginspirasi bahwa kehidupan manusia itu sementara, masih ada sesuatu yang ingin dijangkaui oleh manusia dalam hidupnya yakni kepercayaan akan transendensi Allah sebagai tujuan akhir dari perjalanan hidup manusia. Sifat kesementaraan manusia sebagai makhluk hidup mengajarkan arti penting hidup yakni memiliki keterbatasan. Nilai tapal batas merupakan gagasan Jaspers untuk sedikitnya menghentikan superioritas manusia terhadap makhluk lain. Bagi Jaspers memahami dunia berarti memahami diri sendiri dengan kualitas kesadaran murni, intelek dan eksistensi. Ketiganya saling melengkapi satu sama lain.

\section{Makna Pilihan Hidup}

Gabriel Marcel (1889-1973) menelurkan gagasannya siapakah aku? Pertanyaan ini mencoba menjawab titik-titik ekstrem pilihan hidup manusia. Jawabannya tidak berada pada ekstrem tertentu seperti materialisme atau idealisme. Lebih jauh dari itu, ia menengarai kedua-keduanya sambil mencari makna terdalam dari pilihannya. Materialiseme baginya menghancurkan ciri aktif manusia untuk mencari keberlanjutan hidup sesudah hancurnya ciri-ciri fisik dalam kematian. Sedangkan penolaknannya terhadap idealimse berpaut pada hilangnya kreativitas manusia untuk menentukan nasibnya sendiri karena terkunci oleh ide-ide atau gambaran abstrak yang terberikan sebelumnya. Tidak berhenti pada dua gambaran tersebut, Marcel menguraikan hubungan antara kesadaran manusia dan mengada, aku dan tubuku, serta aku dan Tuhan. Pengenalan tentang manusia untuk Marcel sangat kompleks. Ia menamainya misteri. Sebab pengenalan tentangnya membutuhkan sebuah refleksi mendalam. Manusia merupakan misteri agung yang didekat dengan refleksi dan cinta.

Permenungan dan cinta merupakan esensi dalam eksistensi manusia. Eksistensi manusia merupakan pengejawantahan cinta yang terus menerus dan mengambil bagian dalamnya merupakan tujuan hidup manusia. Hanya dengan cinta setiap orang mengambil bagian yang tak terselami dari perbedaan-perbedaan yang ada. Cinta meluruskan relasi antara suami dan isteri antara aku dan engkau serta mereka dan kita. Cinta itu abadi dan tidak tergerus oleh waktu bahkan kematian sekalipun. Untuk itu, kepercayaan akan cinta merupakan bentuk personalisme. Artinya relasi yang dibangun merupakan relasi pribadi. 
Cinta merupakan jawaban eksistensial manusia. Jawaban tersebut sangat personal baik antarpribadi, alam dan Tuhan sendiri (Weij, 2017: 92)

Gagasan Marcel tentang persona memiliki arti cara memaknai pilihan-pilihan hidup. Makna hidup itu tidak saja bersifat otonom individual. Ia serentak bersifat sosial. Di sana terjalin hubungan intersubjektivitas. Individu meresapi pengalaman konkretnya secara subjektif. Ia mengembalikan segala sesuatu dengan menyatu secara utuh akan pilihan-pilihan hidup yang dijalaninya. Menyelaminya hanya dengan menyadari pengalaman konkret hidup manusia yang aktual. Cinta bukan keadaan objektif. Cinta merupakan sebuah situasi subjektif manusia sebagai cara berada yang sesungguhnya. Dalam cinta tidak ada ruang untuk mengobjektifkan yang lainnya. Cinta melebur segala perbedaan. Hidup sangat bermakna, jika pilihan atas hidup itu diresapi oleh cinta yang tidak bertepi (Maharani, 2012).

5. Penutup: Hidup sebagai sebuah Pilihan

Pergumulan filsafat eksistensial adalah realitas konkret manusia. Realitas tersebut menghadirkan aneka pilihan-pilihan yang mungkin dijalankan oleh manusia. Itu merupakan kenyataan yang tidak dapat dihindari oleh siapapun. Hanya saja intensitas pilihan tersebut berbeda-beda oleh masing-masing orang. Ada yang mengarahkan hidupnya pada tuntunan ilahi seperti pada Kierkegaard, Jaspers dan Marcel. Ada pula yang mengarahkan hidupnya pada keunggulan manusia dan kebebasan seperti pada Nietzche dan Satre. Mereka telah mewarnai sejarah peradapan manusia melalui konteks berfilsafatnya masing-masing. Namun satu hal yang pasti bahwa semua kaum eksistensialis berpedomaan pada fakta subjektif manusia. Manusia bukan benda yang selalu diobjektifkan dan diketahui secara menyeluruh seperti dalam kajian ilmu pengetahuan. Kehadiran eksistensialisme membuka selubung makna tentang cara berada manusia.

Pertama, dinamika hidup manusia. Dinamika hidup manusia ditandai oleh aktivitasnya untuk selalu menjadi lebih baik. Ia tidak berhenti pada titik pusaran kesedihan, rasa putus asa dan kegetiran hidup. Beranjak dari situ ia mulai bertanya tentang keberadaannya di tengah perubahan yang sedang terjadi. Darinya akan muncul sebuah pilihan terhadap hidup yang diyakini sebagai cara hidup.

Kedua, kesadaran. Kesadaran adalah esensi yang ditampilkan dalam filsfata eksistensialisme. Namun, kesadaran tersebut tidak terpisahkan dengan realitas konkret 
manusia. Dalam kajian Marx tentang manusia, kesadaran bersandar pada kekuatan produksi sebagai daya dorong manusia untuk tetap aktif dalam proses kehidupannya. Manusia tidak hidup dari konsepsi dan ide-ide. Sebaliknya ide, gagasan dan cara berpikir manusia ditentukan oleh kebutuhan mendasar manusia seperti makanan, minuman dan lebih luas dari faktor-faktor ekonomi. Marx mengatakan bahwa problem eksistensial "berangkat dari manusia aktif dan nyata, dan berdasarkan kehidupan yang nyata, kami menunjukkan perkembangan refleks dan gema ideologis dari proses kehidupan ini” (Fromm, 2004:14).

Ketiga, praksis hidup. Filsafat eksistensialis memberikan ruang keterbukaan akan pilihan hidup manusia. Ia tidak hanya mengkaji landasan teoretik yang abstrak. Akan tetapi, kajian filsfat eksistensialis memberikan cara hidup baru terkait dengan cara mengaktualisasikan hidup di tengah dunia. Ia tidak bersumber dari ide-ide rigid dan kaku, tetapi pengalaman hidup aktual dijadikan sebagai praksis hidup setelah mendapatkan esensi berupa kesadaran yang menyatu dengan konsep hidup. Penghayatan terhadap ilmu dan permenungan diri adalah tuntutan utama dari filsafat eksistensialis. Dengan demikian pengetahuaan itu diyahati dalam realitas (connaissance vecue).

\section{Daftar Pustaka}

Bakker, A. (2004). Metodologi penelitian filsafat. Kanisius: Yogyakarta

Benton, Ted \& Ian Craib. (2009). Filsafat Ilmu Sosial: Pengantar Filosofis bagi Pemikiran Sosial. Penerbit Ledalero: Maumere.

Ekawati, D. (2017). Eksistensialisme. Tarbawiyah: Jurnal Ilmiah Pendidikan, 12(01), 137-153.

From, Erich. (2004). Konsep Manusia menurut Marx. Pustaka Pelajar: Yogyakarta.

Hardiman, F. B. (2009). Demokrasi deliberatif: menimbang negara hukum dan ruang publik dalam teori diskursus Jurgen Habermas (Vol. 4). Kanisius: Yogyakarta

Horn, H. (1993). Karl Jaspers (1883-1969). Perspectivas: Revista trimestral de educación comparada, (3), 769-788.

Maharani, Septiani Dewiputri. (2012). PANDANGAN GABRIEL MARCEL TENTANG MANUSIA DALAM KONTEKS PERISTIWA BENCANA

ALAM. Jurnal Filsafat. Vol 22 (2)

Munir, M. (2011). Pengaruh Filsafat Nietzsche Terhadap Perkembangan Filsafat Barat Kontemporer. Jurnal Filsafat, 21(2), 134-146. 
Noorzeha, F. (2020). NEW NORMAL AS THE NEW HUMAN: MASA PANDEMI DALAM PERSPEKTIF FILSAFAT MANUSIA SÖREN AABYE KIERKEGAARD DAN RELEVANSINYA PADA KEHIDUPAN MANUSIA MASA DATANG. Sophia Dharma: Jurnal Filsafat Agama Hindu dan Masyarakat, 3(2), 1-16.

Rusdi, R. (2013). Filsafat Idealisme: Implikasinya dalam Pendidikan. Dinamika Ilmu: Jurnal Pendidikan, 13(2).

Van der Weij, P.A, K. Bertens (penerj). (2017). Filsuf-filsuf Besar tentang Manusia, Kompas Gramedia: Jakarta.

Santas, Gerasimos. (2002). Plato dan Freud: Dua Teori tentang Cinta. Penerbit Ledalero: Maumere. 